\title{
HUBUNG ANTARA KECERDASAN EMOSIONAL DAN KECERDASAN SPRITUAL DENGAN KEPUASAN KERJA GURU SEKOLAH DASAR NEGERI SE KECAMATAN DUMAI BARAT KOTA DUMAI
}

\author{
Weni $^{1}$, Zulfan Saam ${ }^{2 *}$, Azhar $^{3}$ \\ ${ }^{1}$ Magister Administrasi Pendidikan, Program Pascasarjana Universitas Riau, \\ Pekanbaru, Indonesia \\ ${ }^{2}$ Program Studi Bimbingan Konseling, Fakultas Keguruan dan IImu Pendidikan, \\ Universitas Riau, Pekanbaru, Riau \\ ${ }^{2}$ Program Studi Pendidikan Bahasa dan Sastra Indonesia, Fakultas Keguruan dan \\ Ilmu Pendidikan, Universitas Riau, Pekanbaru, Riau \\ *zulfan.saam@lecturer.unri.ac.id
}

\begin{abstract}
This study aims to determine the relationship between emotional intelligence and spiritual intelligence with teacher job satisfaction. This study uses a survey method with correlational techniques. The population of the study was the teachers of SDN in Dumai Barat District, Dumai City with a sample of 150 people. The instrument used for data collection is a number of written questions with 4 variations of answer choices. The instrument item validation was tested using product moment correlation, while the instrument reliability test was calculated using the Alpha Conhbach formula. The results showed that (1) there was a significant relationship between spiritual intelligence and job satisfaction of State Elementary School teachers in Dumai Barat District, Dumai City. (2). There is a very strong relationship between spiritual intelligence and job satisfaction of State Elementary School teachers in Dumai Barat District, Dumai City. (3). There is a positive and significant relationship between emotional intelligence and spiritual intelligence together with job satisfaction of State Elementary School teachers in Dumai Barat District, Dumai City. The results of this study are expected to be useful for improving work stress, emotional intelligence and personality of State Elementary School teachers in West Dumai District, Dumai City. The conclusion of this study shows that job satisfaction can be reduced through increasing emotional intelligence and spiritual intelligence either alone or together.
\end{abstract}

Keywords: emotional intelligence, job satisfaction; spiritual intelligence

\section{PENDAHULUAN}

Pada dasarnya kepuasan kerja merupakan sesuatu yang bersifat individual. Setiap individu memiliki tingkat kepuasan yang berbeda-beda sesuai dengan sitem nilai yang berlaku pada dirinya. Makin tinggi penilaian terhadap kegiatan yang dirasakan sesuai dengan keinginan individu, maka makin tinggi kepuasannya 
terhadap kegiatan tersebut. Dengan demikian, kepuasan merupakan evaluasi yang menggambarkan seseorang atas perasaan sikapnya senang atau tidak senang, puas atau tidak puas dalam bekerja (Rivai. 2009).

Kepuasan kerja merupakan salah satu faktor yang sangat penting untuk mendapatkan hasil yang optimal dari pekerjaan yang dikerjakan. Kepuasan kerja guru merupakan hal yang penting dalam mewujudkan berbagai macam program dan tujuan sekolah, hal ini dikarenakan oleh guru yang memiliki kepuasan kerja yang tinggi akan: 1) percaya bahwa dalam proses pekerjaan, organisasi akan memberikan kepuasan, 2) peduli tentang kualitas kerja mereka, 3) lebih terikat pada organisasi, 4) mempunyai kecepatan yang tinggi, 5) lebih produktif (Barnawi \& Arifin, 2012)

Berdasarkan hasil wawancara awal terhadap guru Sekolah Dasar Negeri yang ada di Kecamatan Dumai Barat, masalah-masalah atau fenomena yang timbul berkaitan dengan ketidakpuasan kerja guru adalah sebagi berikut:

1. Guru kurang menyukai pekerjaan mereka yang bersifat rutinitas atau monoton dan menganggap pekerjaan mereka hanya sebagi suatu kewajiban saja.

2. Guru kurang berpartisipasi atau kurang terlibat dalam kegiatan-kegiatan yang dilakukan oleh sekolah.

3. Guru menunda-nunda pekerjaan yang menjadi tanggung jawab mereka, yang merupakan bentuk dari ketidakpuasan mereka dalam bekerja.

4. Guru belum bisa bekerja sama secara baik dengan guru lain di dalam kegiatan sekolah.

Berdasarkan wawancara awal tersebut maka diperoleh informasi bahwa guru belum merasakan kepuasan kerja terhadap berbagai tugas dan kegiatan-kegiatan sekolah. Hal ini diperjelas dengan indikasi sebagai berikut:

1. Guru masih menggunakan perangkat pembelajaran yang lama, meskipun terkadang ada yang tidak sesuai dikarenakan guru merasa bahwa pekerjaan mereka membosankan.

2. Guru hanya marasa mengajar adalah sebuah kewajiban semata.

3. Guru masih kurang memiliki sodelaritas terhadap guru atau tim kerja hal ini terlihat dari kurangnya kekompakkan dan kebersamaan di antara guru dan seringnya terjadi konflik diantara rekan kerja sesama guru. 
4. Guru kurang mengembangkan potensi yang mereka miliki, hal ini terlihat dari cara mereka yang mengajar yang tidak ada perubahan.

Seorang guru harus memiliki kecerdasan emosional dan kecerdasan spiritual yang memadai, karena Kecerdasan emosional dan kecerdasan spiritual ini merupakan modal dasar bagi seorang guru untuk menjadi sosok yang diharapkan dan mampu memberikan pencerahan batin bagi anak didiknya.

Kinerja guru tidak hanya dilihat dari kemampuan kerja yang sempurna, melainkan kemampuan menguasai dan mengelola diri sendiri serta kemampuan dalam membina hubungan dengan orang lain. Kemampuan tersebut dinyatakan oleh Goleman dengan kecerdasan emosional (Emotional Intelligence). Goleman (2006) melalui penelitiannya mengatakan bahwa kecerdasan emosi menyumbang $80 \%$ dari faktor penentu kesuksesan sesorang, sedangkan $20 \%$ yang lain ditentukan oleh IQ (Intelligence Quotient). Penelitian ini memfokuskan peningkatan kinerja SDM melalui faktor internal (individu) karyawan, yaitu kemampuan (ability). Kemampuan seseorang diantaranya ditentukan oleh kecerdasan yang dimilikinya, Menurut Hawari (2016) terdapat beberapa kecerdasan pada diri manusia, diantaranya: kecerdasan intelektual (lihat misalnya Putra \& Sucitra, 2015), kecerdasan emosional, dan kecerdasan spiritual (Wijayanti, \& Rukiyati, 2021). Sebagian besar SDM di negara berkembang termasuk Indonesia masih memiliki kecerdasan emosional yang kurang baik. Hal inilah yang menjadi salah satu penyebab lemahnya kualitas SDM di Indonesia (Mangkunegara, 2010). Kecerdasan emosional adalah kemampuan mengenali emosi diri merupakan kemampuan seseorang dalam mengenali perasaannya sendiri sewaktu perasaan atau emosi itu muncul dan mampu mengenali emosinya sendiri apabila ia memiliki kepekaan yang tinggi atas perasaan mereka yang sesungguhnya dan kemudian mengambil keputusan mengambil keputusankeputusan secara mantap (Goleman, 2004)

Kecerdasan Spiritual yang bertumpu pada bagian dalam diri guru yang berhubungan dengan kearifan di luar ego atau jiwa sadar. Kecerdasan Spiritual menjadikan seorang guru yang benar-benar utuh secara intelektual, emosional dan spiritual. Kecerdasan Spiritual adalah kecerdasan jiwa yang membantu seseorang untuk mengembangkan dirinya secara utuh melalui penciptaan kemungkinan untuk menerapkan nilai-nilai positif, yang berkembang yang memungkinkan otak untuk 
menemukan dan menggunakan makna dalam pemecahan persoalan guru dalam menghadapi anak didiknya. Kecerdasan spiritual yang berkembang dengan baik dapat menjadikan guru memiliki kualitas yaitu suatu modus eksistensi yang dapat membuat guru merasa gembira, menggunakan kemampuannya secara produktif dan dapat menyatu dengan keterampilan dan kemampuan yang ada dalam kompetensi guru tersebut.

Oleh karena itu kepuasaan guru sangat berkorelasi oleh kecerdasan emosional dan kecerdasan spritual guru. Kepuasan kerja guru ditandai dengan munculnya rasa puas dan terselesaikannya tugas-tugas yang jadi tanggung jawab guru secara tepat waktu, selain itu munculnya dedikasi, kegairahan, kerajinan, ketekunan, inisiatif dan kreatifitas kerja yang tinggi dalam bekerja. Berdasarkan fenomena diatas, penulis tertarik untuk membahas lebih dalam dengan malakukan penelitian tentang "Korelasi Antara Kecerdasan Emosional Dan Kecerdasan Spritual Dengan Kepuasan Kerja Guru Sekolah Dasar Negeri Se Kecamatan Dumai Barat Kota Dumai”.

Berdasarkan latar belakang dan pembatasan masalah, maka permasalahan penelitian ini dapat dirumuskan sebagai berikut:

1. Apakah ada hubungan antara kecerdasan emosional dengan kepuasan kerja guru SD Negeri se- Kecamatan Dumai Barat Kota Dumai.

2. Apakah ada hubungan antara kecerdasan spritual dengan kepuasan kerja guru SD Negeri se- Kecamatan Dumai Barat Kota Dumai.

3. Apakah ada hubungan antara kecerdasan emosional dan kecerdasan spritual secara simultan dengan kepuasan kerja guru SD Negeri se- Kecamatan Dumai Barat Kota Dumai.

Penelitian ini bertujuan untuk:

1. Menganalisis hubungan antara kecerdasan emosional dengan kepuasan kerja guru SD Negeri se- Kecamatan Dumai Barat Kota Dumai.

2. Menganalisis hubungan antara kecerdasan spritual dengan kepuasan kerja guru SD Negeri se- Kecamatan Dumai Barat Kota Dumai.

3. Menganalisis hubungan antara kecerdasan emosional dan kecerdasan spritual secara simultan dengan kepuasan kerja guru SD Negeri seKecamatan Dumai Barat Kota Dumai. 
4. Penelitian ini dapat menjadi suatu masukan untuk memajukan dunia pendidikan oleh Dinas Pendidikan Kota Dumai.

5. Dapat menjadi bahan masukan bagi lembaga pendidikan lainnya dalam usaha untuk membangun keunggulan dalam bersaing secara positif untuk memajukan dunia pendidikan.

Istilah kepuasan kerja dalam bahasa inggris disebut dengan job satisfaction. Kepuasan kerja merupakan ikatan emosi seorang berupa perasaan senang atau tidak senang terhadap hasil kerja yang telah dilakukannya. Kepuasan kerja mencerminkan perasaan seseorang terhadap pekerjaannya. Hal ini tampak dalam sikap positif terhadap pekerjaan dan segala sesuatu yang dihadapi di lingkungan kerjanya. Robbins mendefinisikan bahwa kepuasan kerja (job satisfaction) adalah suatu perasaan positif tentang pekerjaan seseorang yang merupakan hasil dari sebuah evaluasi karakteristiknya (Robbins \& Judge, 2012).

Sedangkan menurut Luthans, Luthans, dan Palmer (2016), kepuasan kerja adalah hasil dari persepsi karyawan mengenai seberapa baik pekerjaan mereka memberikan hal yang dinilai penting. Menurutnya, terdapat tiga dimensi yang diterima secara umum dalam kepuasan kerja yaitu 1) kepuasan kerja merupakan respon emosional terhadap situasi kerja, 2) kepuasan kerja sering ditentukan menurut seberapa baik hasil yang dicapai memenuhi atau melampaui harapan, 3) kepuasan kerja mewakili beberapa sikap yang berhubungan.

Lebih dalam lagi Rivai dan Murni (2009) mengemukakan kepuasan kerja pada dasarnya adalah security feeling" (rasa aman) dan mempunyai segi-segi: a) segi sosial ekonomi (gaji dan jaminan sosial), b) segi sosial psikologi: 1) kesempatan untuk maju, 2) kesempatan mendapatkan penghargaan, 3) berhubungan dengan masalah pengawasan, 4) berhubungan dengan pergaulan antara karyawan dengan karyawan dan antara karyawan dengan atasannya.

Berdasarkan konsep-konsep yang telah dikemukakan di atas dapat disimpulkan bahwa kepuasan kerja adalah perasaan senang atau tidak senang yang berpengaruh pada perbuatan seseorang terhadap pelaksanaan pekerjaan dan hasil dari yang dia lakukan yang ditandai dengan: (1) menyukai pekerjaan, (2) suasana dan lingkungan kerja, (3) mempunyai sikap positif dalam menghadapi kesulitan, (4) hubungan dengan rekan kerja. 
Segal (2011) menyatakan bahwa kecerdasan emosional diciptakan untuk menggambarkan kecerdasan hati. Wilayah kecerdasan emosional adalah hubungan antar pribadi; kecerdasan emosional bertanggungjawab atas harga diri, kesadaran diri, kepekaan social dan kemampuan adaptasi sosial. Segal juga menyatakan bahwa hati dan akal adalah dua bagian dari satu keseluruhan. Kecerdasan emosional sesungguhnya membantu pikiran rasional (akal). Kecerdasan emosional memungkinkan seseorang untuk menentukan pilihan-pilhan yang baik tentang apa yang kita makan, siapa yang akan dijadikan teman, pekerjaan apa yang akan dilakukan dan bagaimana menjaga keseimbangan antara kebutuhan pribadi dan kebutuhan orang lain.

Adnan (dalam Agustian, 2007) menyatakan bahwa hati nurani akan menjadi pembimbing terhadap apa yang harus ditempuh dan apa yang harus diperbuat. Artinya setiap manusia sebenarnya telah memiliki radar hati sebagai pembimbingnya. Agustian menyatakan bahwa yang menjadi masalah, apakah anda jujur pada diri anda sendiri? seberapa cermat anda merasakan perasaan terdalam dalam diri anda? Seringkah anda tidak mempedulikannya. Berdasarkan kenyataan ini Agustian (2007) menyimpulka kunci kecerdasan emosional adalah kejujuran pada suara hati.

Berdasarkan uraian yang telah dikemukan diatas, kecerdasan emosional adalah suara hati individu dalam mendeteksi, mengenali, merasakan, memahami, dan menafsirkan emosi diri sendiri dan emosi orang lain dan menanggapi dengan efektif energi emosi dalam kehidupan dan pekerjaan sehari-hari sehingga meningkatkan cara berfikir dan bertindak, dengan indikator 1). Mengenali emosi diri, 2). mengelola emosi diri, 3). mengenali emosi orang lain dan 4). membina hubungan dengan orang lain.

Menurut Effendi $(2015,209)$ kecerdasan spiritual adalah kesadaran yang dengannya kita tidak hanya mengakui nilai-nilai yang ada, tetapi juga secara kreatif kita menemukan nilai-nilai baru. Kecerdasan spritual adalah kecerdasan yang tidak bergantung pada budaya dan nilai, kecerdasan yang mendahului seluruh nilai spesifik dan budaya mana pun.

Vendy (2010) kecerdasan spiritual adalah kecerdasan yang merefleksikan antara unsur jasmani dan rohani. Spiritual Quotient adalah kecerdasan yang 
menyangkut fungsi jiwa sebagai perangkat internal diri memiliki kemampuan dan kepekaan dalam melihat makna yang ada dibalik kenyataan apa adanya. Orang yang memiliki SQ tinggi mampu memaknai penderitaan hidup dengan memberi makna yang positif pada peristiwa, bahkan masalah yang dialaminya, dengan memberi makna yang positif itu, ia mampu membangkitkan jiwanya, melakukan perbuatan dan tindakan yang positif.

Agustian (2007) mengatakan ada tujuh sifat yang dapat dijadikan indikator dalam kecerdasan spiritual dalam memberikan meaning atau nilai bagi yang melaksanakannya

a. Jujur, adalah wujud pengabdian manusia kepada sifat Allah yang berupa AlMukmin.

b. Tanggungjawab, adalah wujud pengabdian manusia kepada Allah yang berupa Al-Wakil.

c. Displin, adalah wujud pengabdian manusia kepada sifat Allah yang berupa A/Matiin.

d. Kerjasama, adalah wujud pengabdian manusia kepada Allah yang berupa A/Jami'.

e. Adil, adalah wujud pengabdian kepada Allah yang berupa Al-Adl.

f. Visioner adalah wujud pengabdian kepada Allah yang berupa Al-Aakhir.

g. Peduli, adalah wujud pengabdian manusia kepada Allah yang berupa A/sami' dan Al-Bashir.

\section{METODE PENELITIAN}

Penelitian ini dilakukan di seluruh SD Negeri Dumai Barat Kota Dumai. Penelitian ini dilakukan pada bulan September - Oktober 2020.

Metode penelitian yang digunakan dalam penelitian ini adalah metode survei dengan pendekatan korelational, yang diarahkan untuk menguji hubungan antar variabel yang dinyatakan pada hipotesis. Variabel penelitian ini terdiri atas dua variabel bebas yaitu kecerdasan emosional dan kecerdasan spritual, serta satu variabel terikat yaitu kepuasan kerja guru SDN Negeri Dumai Barat Kota Dumai.

Populasi dalam penelitian ini adalah seluruh guru SD Negeri di Kecamatan Dumai Barat Kota Dumai yang berjumlah 238 orang, Berdasarkan tabel Krejcie

Weni, Z. Saam, \& Azhar, Hubungan antara Kecerdasan Emosional dan Spritual dengan Kepuasan 
diketahui bahwa untuk 10 sekolah dengan jumlah guru 238 sehingga diperoleh sampel penelitian sebesar 150 orang guru.

Teknik analisa data yang digunakan adalah teknik analisa statistik deskriptif dan analisa infrensial. Yang akan digunakan untuk memberikan gambaran tentang nilai terendah, nilai tertinggi, rentangan, rata-rata (mean), median, modus, dan simpangan baku, serta tabel distribusi frekuensi yang dilengkapi histogram data setiap variabel.

\section{Uji Normalitas}

Uji normalitas dapat digunakan uji kolmogorav-Smirnov, dengan kriterianya adalah signifikansi untuk uji dua sisi hasil perhitungan lebih besar dari 0,05 yang berarti berdistribusi normal.

\section{Uji Linearitas}

Regresi dapat dikatakan linier apabila $\mathrm{F}$ hitung lebih kecil dari $\mathrm{F}$ tabel dengan taraf signifikansi $\alpha=0.05$.

\section{Uji Signifikansi Regresi}

Uji Signifikansi Regresi ini dilakukan untuk melihat apakah persamaan regresi yang diperoleh berarti, apabila digunakan sebagai kesimpulan antar variabel yang dianalisis.

\section{Uji Hipotesis}
a. Perhitungan Koefisien Determinasi
b. Uji Korelasi Product Moment
c. Uji Korelasi Parsial
d. Uji Korelasi Berganda
e. Hipotesis Statistik

\section{HASIL DAN PEMBAHASAN}

\section{Hasil Penelitian}

Sebagai alat analisis uji validitas digunakan teknik korelasi Product Moment. Berikut ini disajikan hasil uji validitas instrumen berdasarkan hasil perhitungan dengan menggunakan SPSS.

Uji Reliabilitas merupakan ukuran satuan kestabilan dan konsistensi responden dalam menjawab hal yang berkaitan dengan bentuk-bentuk pertanyaan yang 
merupakan dimensi pernyataan dalam kuisioner merupakan pernyataan yang reliabel. Dari perhitungan dengan SPSS.

Deskripsi data yang menjadi komponen dalam penelitian ini adalah data tentang kecerdasan emosional, kecerdasan spiritual, dan kepuasan kerja guru Sekolah Dasar Negeri se-Kecamatan Dumai Barat Kota Dumai. Adapun variabel yang digunakan pada penelitian ini diantaranya variabel terikat $(Y)$ adalah kepuasan kerja guru, sedangkan variabel bebas pertama $\left(X_{1}\right)$ adalah kecerdasan emosional dan variabel bebas kedua $\left(\mathrm{X}_{2}\right)$ adalah kecerdasan spritual.

Jumlah subjek penelitian yang telah memenuhi syarat untuk dianalisis ada 150 orang. Untuk memperoleh gambaran mengenai karakteristik sampel dilakukan melalui deskripsi data skor dari subjek penelitian untuk masing-masing variabel. Untuk itu berikut ini disajikan harga rata-rata, simpangan baku, median, modus, distribusi frekuensi, diagram batang, dan kategori skor.

Bahwa hasil perhitungan terhadap skor kepuasan kerja guru Sekolah Dasar Negeri se-Kecamatan Dumai Barat Kota Dumai menghasilkan: (1) skor rata-rata = 84,34 ; (2) median $=84$; (3) modus $=84$, dan (4) simpangan baku = 3,843. Hubungan antara mean, median, dan modus, ditentukan oleh kesimetrian kurva distribusi data. Berdasarkan perhitungan statistik data kepuasan kerja guru, nilai rata-rata berdekatan dengan nilai median dan nilai modus. Dengan demikian, dapat disimpulkan bahwa distribusi skor variabel kepuasan kerja guru pada populasi mengikuti distribusi normal.

Data variabel kecerdasan emosional diperoleh melalui 31 butir pernyataan yang terdapat pada instrumen penelitian. Dapat dijelaskan bahwa hasil perhitungan terhadap skor kecerdasan emosional guru Sekolah Dasar Negeri se-Kecamatan Dumai Barat Kota Dumai menghasilkan: (1) skor rata-rata =99,98; (2) median = 100; (3) modus $=102$, dan (4) simpangan baku $=4,657$. Hubungan antara mean, median, dan modus, ditentukan oleh kesimetrian kurva distribusi data.

Data variabel kecerdasan spritual diperoleh melalui 25 butir pernyataan yang terdapat pada instrumen penelitian. Skala yang digunakan pada butir pernyataan instrumen adalah skala Likert 5 poin. Secara teoritis, skor terendah yang dicapai responden adalah 85 dan skor teoretis dapat dijelaskan bahwa hasil perhitungan terhadap skor kecerdasan spritual guru Sekolah Dasar Negeri seKecamatan Dumai

Weni, Z. Saam, \& Azhar, Hubungan antara Kecerdasan Emosional dan Spritual dengan Kepuasan 
Barat Kota Dumai menghasilkan: (1) skor rata-rata =94,56; (2) median = 95; (3) modus = 95, dan (4) simpangan baku =3,5473. Hubungan antara mean, median, dan modus, ditentukan oleh kesimetrian kurva distribusi data. Berdasarkan perhitungan statistik data kecerdasan spritual, nilai rata-rata berdekatan dengan nilai median dan nilai modus. Dengan demikian, dapat disimpulkan bahwa distribusi skor variabel kecerdasan spritual pada populasi mengikuti distribusi normal.

Analisi data menguji hipotesis penelitian dilakukan dengan menggunakan analiis statistik parametik, yaitu analisis korelasi sederhana dan berganda. Sebelum pengujian hipotesis perlu dilakukan pengujian persyaratan analisis untuk keperluan memprediksi maupun untuk keperluan pengujian hipotesis. Uji persyaratan dalam penelitian ini adalah uji normalitas dan uji linearitas.

Uji normalitas dilakukan untuk mengetahui normal tidaknya sebarab data yang akan dianalisis. Data tersebut meliputi variabel kepuasan kerja (Y), kecerdasan emosional $\left(X_{1}\right)$, dan kecerdasan Spritual $\left(X_{2}\right)$. Uji normalitas menggunakan SPSS versi 23.

Uji normalitas berguna untuk mengetahui apakah variabel dependen, independen atau keduanya berdistribusi normal. Jika data berdistribusi normal, alat analisis parametrik termasuk model regresi dapat digunakan. Mendekteksi data berdistribusi normal atau tidak, dapat diketahui dengan nilai signifikansi uji Kolmogorov-Smirnov. Untuk itu, perhitungan uji normalitas data variabel kepuasan kerja guru $(Y)$, variabel kecerdasan emosional $\left(X_{1}\right)$, dan variabel kecerdasan spritual $\left(\mathrm{X}_{2}\right)$ dilakukan dengan uji Kolmogorov-Smirnov. Berikut disajikan hasil uji normalitas berdasarkan perhitungan dengan SPSS 23.

Kenormalan data pada penelitian ini dapat diketahui dari uji normalitas Kolmogorov-Smirnov dari masing-masing variabel. Kriteria keputusan didasarkan atas signifikasi. Apabila signifikansi t hitung lebih besar daripada taraf signifikasi $\alpha$ yang ditentukan yaitu 0,05, berarti data berdistribusi normal. Untuk melakukan pengujian normalitas data penelitian diperlukan hipotesis sebagai berikut :

$\mathrm{H}_{0}$ : data berdistribusi normal

$\mathrm{H}_{\mathrm{a}}$ : data tidak berdistribusi normal

Berdasarkan tabel 4.9 pada kolom Kolmogorov-Smirnov diperoleh nilai signifikansi variabel kepuasan kerja (Y) sebesar 0,200, variabel kecerdasan 
emosional $\left(X_{1}\right)$ sebesar 0,200 dan variabel kecerdasan spiritual $\left(X_{2}\right)$ sebesar 0,200. Nilai signifikansi dari masing-masing variabel penelitian lebih besar daripada nilai signifikansi 0,05 yang berarti bahwa $\mathrm{H}_{0}$ diterima atau data dari masing-masing variabel berdistribusi normal.

Uji linearitas digunakan untuk menguji kelinearan masing-masing variabel bebas terhadap variabel terikat. Oleh sebab itu, pengujian linearitas pada penelitian ini terdiri dari dua yaitu: (1) bentuk hubungan antara kecerdasan emosional dengan kepuasan kerja guru dan (2) bentuk hubungan antara kecerdasan spritual dengan kepuasan kerja guru.

Pengujian persyaratan ini dilakukan untuk menentukan linear atau tidaknya distribusi data penelitian sehingga dapat ditentukan bentuk analisis regresi yang dipergunakan. Hipotesis yang digunakan untuk menguji linearitas garis regresi tersebut adalah :

$\mathrm{H}_{0}$ : Model regresi berbentuk linear

$\mathrm{H}_{\mathrm{a}}$ : Model regresi tidak berbentuk linear

Hasil uji linearitas garis regresi berdasarkan data yang terdapat pada tabel 4.10 di atas, menunjukkan nilai signifikansi pada baris Linearity sebesar 0,000. Nilai signifikansi (Sig.) lebih kecil daripada nilai signifikansi alpha $(0,000<0,05)$. Dengan demikian, $\mathrm{H}_{0}$ diterima. Kesimpulannya, model regresi yang terbentuk adalah linear.

Hasil uji linearitas garis regresi berdasarkan data yang terdapat pada tabel 4.11 di atas, menunjukkan nilai signifikansi pada baris Linearity sebesar 0,000. Nilai signifikansi (Sig.) lebih kecil dari pada nilai signifikansi alpha $(0,000<0,05)$. Dengan demikian, $\mathrm{H}_{0}$ diterima. Kesimpulannya, model regresi yang terbentuk adalah linear.

Dalam penelitian ini, pengujian hipotesis bertujuan untuk menguji hubungan antara kecerdasan emosional $\left(X_{1}\right)$ dan kecerdasan spiritual $\left(X_{2}\right)$ dengan kepuasan kerja guru (Y) Sekolah Dasar Negeri seKecamatan Dumai Barat Kota Dumai, baik secara sendiri-sendiri maupun secara bersama-sama. Teknik analisis data yang digunakan untuk mengetahui hubungan antarvariabel tersebut adalah dengan menggunakan regresi dan korelasi.

Hipotesis pertama yang diuji dalam penelitian ini adalah: "Terdapat hubungan positif dan signifikan antara kecerdasan emosional dengan kepuasan kerja guru". Untuk mengetahui derajat keberartian persamaan regresi sederhana perlu dilakukan 
pengujian signifikansi linearitas persamaan dengan uji F sebagaimana diperoleh nilai $p$-value $\alpha=0,000$. Nilai signifikansi 0,000 tersebut dikonsultasikan dengan nilai $\alpha=$ 0,05 . Oleh karena nilai signifikansi lebih kecil dari nilai a $(0,000<0,05)$, maka dapat disimpulkan bahwa koefisien regresi signifikan.

Berdasarkan pengujian signifikansi regresi, persamaan regresi yang dihasilkan merupakan persamaan regresi linear dan signifikan. Oleh karena itu, persamaan yang digunakan dapat digunakan untuk menjelaskan dan mengambil kesimpulan lebih lanjut. Selanjutnya, berdasarkan perhitungan SPSS 23 diperoleh koefisien regresi bahwa hubungan antara kecerdasan emosional dengan kepuasan kerja guru ditunjukkan oleh persamaan regresi $\hat{Y}=33,359+0,510 X_{1}$. Berdasarkan persamaan regresi tersebut, diketahui bahwa konstanta sebesar 33,359. Hal ini berarti, jika skor kecerdasan emosional sebesar 0, skor kepuasan kerja sebesar 33,359. Maka, setiap kenaikan skor kecerdasaan emosional akan diikuti kenaikan skor kepuasan kerja 0,510 pada arah yang sama dengan konstanta 33,359.

Kaidah keputusannya adalah $\mathrm{H}_{0}$ diterima jika nilai t-hitung lebih besar daripada t-tabel dan $\mathrm{H}_{0}$ ditolak jika t-hitung lebih kecil daripada nilai t-tabel. Dari output koefisien regresi yang terdapat pada tabel 4.13 di atas, diperoleh nilai t-hitung sebesar 9,263. Nilai t-hitung dibandingkan dengan nilai t-tabel (uji dua sisi, $\alpha=0,05$ dengan derajat kebebasan (df) k-1 diperoleh nilai t-tabel sebesar 1,655. Ternyata, nilai t-hitung lebih besar daripada nilai t-tabel $(9,263>1,655)$. Dengan demikian, $\mathrm{H}_{0}$ diterima. Jadi, dapat disimpulkan bahwa terdapat hubungan yang signifikan antara kecerdasan emosional dengan kepuasan kerja guru Sekolah Dasar Negeri seKecamatan Dumai Barat Kota Dumai.

Lebih lanjut, untuk mengetahui derajat kekuatan hubungan antara kecerdasan emosional dengan kepuasan kerja guru dihitung dengan mempergunakan teknik korelasi Pearson Product Moment dengan hasil koefisien korelasi antara kecerdasan emosional $\left(X_{1}\right)$ dengan kepuasan kerja guru $(Y)$ adalah 0,606 . Artinya, terdapat hubungan yang kuat antara kecerdasan emosional dengan kepuasan kerja guru. Koefisien menunjukkan nilai positif yang berarti semakin baik kecerdasan emosional, maka semakin baik pula kepuasan kerja guru. Koefisien korelasi 0,606 menghasilkan nilai koefisien determinasi $\left(r^{2}\right)$ sebesar 0,367. Dengan demikian, 
kecerdasan emosional memberikan kontribusi sebesar 36,7 \% terhadap kepuasan kerja.

Hipotesis kedua yang diuji dalam penelitian ini adalah: "Terdapat hubungan positif dan signifikan antara kecerdasan spiritual dengan kepuasan kerja guru". Untuk mengetahui derajat keberartian persamaan regresi sederhana dilakukan pengujian signifikansi linearitas persamaan dengan uji $\mathrm{F}$ diperoleh nilai $p$-value $\alpha=$ 0,000 . Nilai signifikansi 0,000 tersebut dikonsultasikan dengan nilai $\alpha=0,05$. Oleh karena nilai signifikansi lebih kecil dari nilai a $(0,000<0,05)$, maka dapat disimpulkan bahwa koefisien regresi signifikan.

Berdasarkan pengujian signifikansi regresi, persamaan regresi yang dihasilkan merupakan persamaan regresi linear dan signifikan. Oleh karena itu, persamaan yang digunakan dapat digunakan untuk menjelaskan dan mengambil kesimpulan lebih lanjut. Kemudian, berdasarkan perhitungan SPSS 23 diperoleh koefisien regresi bahwa hubungan antara kecerdasan spiritual dengan kepuasan kerja guru ditunjukkan oleh persamaan regresi $Y=31,817+0,555 X_{2}$. Berdasarkan persamaan regresi tersebut, diketahui bahwa konstanta sebesar 31,817. Hal ini berarti, jika skor kecerdasan spiritual sebesar 0, skor kepuasan kerja sebesar 31,817. Maka, setiap kenaikan skor kecerdasan spiritual akan diikuti kenaikan skor kepuasan kerja guru 0,555 pada arah yang sama dengan konstanta 31,817.

Kaidah keputusannya adalah $\mathrm{H}_{0}$ diterima jika nilai t-hitung lebih besar daripada t-tabel dan $\mathrm{H}_{0}$ ditolak jika t-hitung lebih kecil daripada nilai t-tabel. Dari output koefisien regresi yang terdapat pada tabel 4.16 di atas, diperoleh nilai t-hitung sebesar 7,262. Nilai t-hitung dibandingkan dengan nilai t-tabel (uji dua sisi, $\alpha=0,05$ dengan derajat kebebasan (df) k-1 diperoleh nilai t-tabel sebesar 1,655. Ternyata, nilai t-hitung lebih besar daripada nilai t-tabel $(7,262>1,655)$. Dengan demikian, $\mathrm{H}_{0}$ diterima. Jadi, dapat disimpulkan bahwa terdapat hubungan yang signifikan antara kecerdasan spiritual dengan kepuasan kerja guru Sekolah Dasar Negeri seKecamatan Dumai Barat Kota Dumai.

Untuk mengetahui derajat kekuatan hubungan kecerdasan spiritual dengan kepuasan kerja guru, dapat digunakan koefisien korelasi antara kecerdasan spiritual $\left(\mathrm{X}_{2}\right)$ dengan kepuasan kerja guru $(\mathrm{Y})$ adalah 0,513. Artinya, terdapat hubungan yang sangat kuat antara kecerdasan spiritual dengan kepuasan kerja guru Sekolah Dasar 
Negeri seKecamatan Dumai Barat Kota Dumai. Koefisien menunjukkan nilai positif yang berarti semakin tinggi kecerdasan spiritual, maka semakin baik pula kepuasan kerja guru Sekolah Dasar Negeri seKecamatan Dumai Barat Kota Dumai. Koefisien korelasi 0,513 menghasilkan nilai koefisien determinasi $\left(r^{2}\right)$ sebesar 0,263. Dengan demikian, kecerdasan spiritual memberikan kontribusi sebesar $26,3 \%$ terhadap kepuasan kerja guru.

Hipotesis ketiga yang diuji dalam penelitian ini adalah: "Terdapat hubungan positif dan signifikan antara kecerdasan emosional dan kecerdasan spritual secara bersama-sama dengan kepuasan kerja guru Sekolah Dasar Negeri seKecamatan Dumai Barat Kota Dumai". Untuk pengujian signifikansi dan linearitas persamaan regresi ganda antara kecerdasan emosional dan kecerdasan spritual secara bersama-sama dengan kepuasan kerja guru dapat diperoleh nilai probabilitas signifikansi sebesar 0,000 . Nilai signifikansi lebih kecil daripada nilai signifikansi $(0,000<0,05)$. Kaidah keputusan adalah $\mathrm{H}_{0}$ terima jika nilai signifikansi lebih kecil daripada nilai $\alpha=0,05$ dan $\mathrm{H}_{0}$ tolak jika nilai signifikansi lebih besar daripada nilai $\alpha$ $=0,05$. Dengan demikian, keputusannya adalah $\mathrm{H}_{0}$ diterima. Kesimpulannya, terdapat hubungan yang signifikan antara kecerdasan emosional dan kecerdasan spritual secara bersama-sama dengan kepuasan kerja guru. Koefisien regresi ganda diperoleh persamaan regresi ganda yang menyatakan hubungan fungsional antara kecerdasan emosional $\left(X_{1}\right)$ dan kecerdasan spiritual $\left(X_{2}\right)$ secara bersama-sama dengan kepuasan kerja guru $(Y)$ yang ditunjukkan dengan persamaan regresi $Y=$ $22,214+0,394 X_{1}+0,241 X_{2}$. Maka, setiap peningkatan satu satuan skor kecerdasan emosional dan kecerdasan spiritual secara bersama-sama dapat meningkatkan skor kepuasan kerja guru masing-masing 0,394 dan 0,241 pada konstanta 22,214.

Untuk mengetahui derajat kekuatan hubungan antara kecerdasan emosional dan kecerdasan spritual secara bersama-sama dengan kepuasan kerja guru, digunakan koefisien korelasi ganda yang hasilnya antara kecerdasan emosional dan kecerdasan spiritual secara bersama-sama dengan kepuasan kerja guru sebesar 0,630 . Hal ini menunjukkan terdapat hubungan yang sangat kuat antara kecerdasan emosional dan kecerdasan spiritual secara bersama-sama dengan kepuasan kerja guru.

Weni, Z. Saam, \& Azhar, Hubungan antara Kecerdasan Emosional dan Spritual dengan Kepuasan 
Untuk koefisien determinasi, diperoleh nilai $R^{2}$ sebesar 0,397 . Ini berarti, persentase sumbangan variabel independen (kecerdasan emosional dan kecerdasan spritual) secara bersama-sama terhadap variabel dependen (kepuasan kerja guru) sebesar 39,7\%. Dengan kata lain, variasi variabel kecerdasan emosional dan variabel kecerdasan spritual secara bersama-sama mampu menjelaskan sebesar 39,7\% variasi variabel kepuasan kerja guru. Sisanya, 60,3\% dipengaruhi oleh variabel lain yang tidak dimasukkan dalam model penelitian ini.

\section{Pembahasan Peneltian}

Berdasarkan hasil pengujian yang dipaparkan di atas menunjukkan bahwa (1) terdapat hubungan kecerdasan emosional dengan kepuasan kerja guru (2) terdapat hubungan kecerdasan spritual dengan kepuasan kerja guru, (3) dan terdapat hubungan kecerdasan emosional dan kecerdasan spiritual secara bersama-sama dengan kepuasan kerja guru. Hasil penelitian menunjukkan terdapat hubungan yang positif dan signifikan antara kecerdasan emosional dengan kepuasan kerja guru. Koefisien korelasi $r=0,606$ yang menunjukkan interprestasi korelasi berada pada kategori $s$ kuat. Artinya tingkat keeratan hubungan kecerdasan emosional $\left(X_{1}\right)$ dengan kepuasan kerja guru $(\mathrm{Y})$ sangat erat. Artinya kepuasan kerja guru dipengaruhi oleh kecerdasan emosional sebesar 0,606 atau 60,6 \% sedangkan sisanya $39,4 \%$ dipengaruhi oleh variabel lain.

Dapat dipahami mengapa kecerdasan emosional mempunyai hubungan positif dan signifikan dengan kepuasan kerja guru. Jika seseorang guru memiliki kecerdasan emosional yang tinggi, cenderung dapat meningkatkan kinerjanya disekolah.

Hal ini sesuai dengan teori yang dikemukakan oleh Sherman (dalam Edison dkk, 2016:183), bahwa kecerdasn emosional dapat memberikan "energi perilaku" pada gilirannya dapat meningkatkan kinerja atau kepuasan kerja.

Berdasarkan pendapat tersebut diketahui bahwa kecerdasan emosional adalah sesuatu yang dapat mengontrol dalam diri individu untuk melaksanakan tugas dan kewajibannya guna mencapai tujuan tertentu. Kecerdasan emosional merupakan salah satu unsur penting bagi seorang guru dalam rangka mencapai suatu keberhasilan dalam proses pembelajaran. Seorang guru memiliki kecerdasan 
emosional yang baik dikarenakan terpenuhinya kebutuhan-kebutuhan yang muncul akibat hubungannya dengan lingkungan sekolah, sehingga dapat mencapai suatu hasil yang baik sesuai dengan tujuan yang telah direncanakan.

Hasil penelitian menunjukkan terdapat hubungan yang positif dan signifikan antara kecerdasan spiritual dengan kepuasan kerja guru. Koefisien korelasi $r=0,513$ yang menunjukkan interprestasi korelasi berada pada kategori ssedang. Artinya tingkat keeratan hubungan kecerdasan spiritual $\left(\mathrm{X}_{2}\right)$ dengan kepuasan kerja guru $(\mathrm{Y})$ berhubungan erat. Artinya kepuasan kerja guru dipengaruhi oleh kecerdasan spiritual sebesar 0,513 atau $51,3 \%$ sedangkan sisanya $48,7 \%$.

Dapat dipahami mengapa kecerdasan spiritual mempunyai hubungan positif dan signifikan dengan kepuasan kerja guru. Jika seseorang guru memiliki kecerdasan spiritual yang tinggi, cenderung dapat meningkatkan kinerja dan kepuasan kerja guru disekolah.

Hasil penelitian menunjukkan hubungan antara kecerdasan emosional dan kecerdasan spiritual secara bersama-sama dengan kepuasan kerja guru menghasilkan koefisien korelasi sebesar 0,630. Hal ini menunjukkan tingkat hubungan secara simultan antara kecerdasan emosional $\left(\mathrm{X}_{1}\right)$ dan kecerdasan spiritual $\left(\mathrm{X}_{2}\right)$ dengan kepuasan kerja guru $(\mathrm{Y})$. Kekuatan hubungan antara kecerdasan emosional $\left(X_{1}\right)$ dengan kepuasan kerja guru dengan korelasi person antara kecerdasan spiritual $\left(\mathrm{X}_{2}\right)$ dengan kepuasan kerja guru $(\mathrm{Y})$ sebesar 0,630 atau $63 \%$ sedangkan sisanya $37 \%$ dipengaruhi oleh faktor lain.

Dari hasil penelitian tersebut dapat dipahami bahwa seseorang yang memiliki kecerdasan emosional yang tinggi dan memiliki kecerdasan spiritual yang tinggi maka mereka pasti mendapatkan kepuasan kerja yang baik. Berdasarkan hasil penelitian pada guru Sekolah Dasar Negeri se Kecamatan Dumai Barat Kota Dumai diperoleh kesimpulan bahwa tingkat kecerdasan emosional dan kecerdasan spiritual secara simultan berhubungan dengan kepuasan kerja guru.

\section{SIMPULAN}

Berdasarkan hasil penelitian yang telah dilakukan, analisis, dan uji hipotesis yang ada dalam penelitian ini, maka dapat ditarik kesimpulan sebagai berikut: 
1. Variabel kecerdasan emosional memiliki hubungan yang positif dan signifikan dengan kepuasan kerja guru Sekolah Dasar Negeri seKecamatan Rumbai Dumai Barat Kota Dumai. Hubungan antara kecerdasan emosional dengan kepuasan kerja guru menghasilkan koefisien korelasi 0,606. Hubungan variabel kecerdasan emosional yang signifikan ini membuktikan bahwa kecerdasan emosional merupakan salah satu faktor penentu kepuasan kerja guru.

2. Variabel kecerdasan spiritual memiliki hubungan yang positif dan signifikan. dengan kepuasan kerja guru Sekolah Dasar Negeri se Kecamatan Dumai Barat Kota Dumai. Hubungan antara kecerdasan spiritual dengan kepuasan kerja guru menghasilkan koefisien korelasi 0,513. Hubungan variabel kecerdasan spritual yang signifikan ini membuktikan bahwa kecerdasan spiritual merupakan salah satu faktor penentu kepuasan kerja guru.

3. Variabel kecerdasan emosional dan kecerdasan spiritual secara bersamasama memiliki hubungan yang positif dan signifikan dengan kepuasan kerja guru Sekolah Dasar Negeri seKecamatan Dumai Barat Kota Dumai. Hubungan antar variabel ini secara bersama-sama memberikan korelasi sebesar 0,630 dengan kepuasan kerja guru. Dengan demikian, jika kecerdasan emosional dan kecerdasan spiritual meningkat, akan semakin meningkatkan kepuasan kerja guru.

\section{SARAN}

Berdasarkan kesimpulan dan implikasi yang telah dikemukakan diatas, maka diajukan beberapa saran sehubungan dengan upaya-upaya peningkatan kecerdasan emosional dan kecerdasan spiritual untuk meningkatkan kepuasan kerja guru di Sekolah Dasar Negeri seKecamatan Dumai Barat Kota Dumai. Saran-saran tersebut akan dikemukakan sebagai berikut :

1. Perlunya melakukan pembinaan secara berkala tentang kecerdasan emosional dan kecerdasan spiritual yang dilakukan instansi terkait kepada guru untuk berpandangan ke masa depan tanpa memandang masa lalu dan hendaknya bersifat inovatif. 
2. Guru mestinya lebih memperhatikan kecerdasan emosional dan kecerdasan spiritual sebagai aspek kepribadian yang penting diketahui implikasinya terhadap pekerjaan guru sehingga dapat dijadikan acuan dalam meningkatkan kepuasan kerja guru.

3. Perlu adanya perbaikan dalam kepuasan kerja guru di sekolah khususnya dalam pemberian imbalan pekerjaan bagi guru karena guru merasakan kepuasan bekerja apabila pekerjaan yang dilakukannya setimpal dengan gaji yang diterimanya.

4. Bagi peneliti lain, selanjutnya dapat dilakukan dengan lebih memperdalam materi dari masing-masing variabel yang dapat meningkatkan kepuasan kerja guru seperti komunikasi interpersonal, budaya organisasi, gaji, kompetensi guru, sarana prasarana, peningkatan kesejahteraan guru, kepemimpinan kepala sekolah dan lain-lain.

\section{DAFTAR PUSTAKA}

Agustian, A G. (2007). Emotional Spritual Quotionst. Jakarta: Erlangga

Efendi, A. (2015). Revolusi kecerdasan Abad 21: Kritik MI, EI, SQ, AQ, \& Succesful Intelligence Atas IQ. Bandung: Penerbit Alfabeta.

Goleman, D., Boyatzis, R., \& Mckee, A. (2004). Kepemimpinan berdasarkan kecerdasan emosi. Bandung: PT. Gramedia Pustaka Utama.

Goleman, D. (2006). Emosional Intelligence. Terjemahan T. Hermaya. Jakarta: Gramedia Pustaka Utama.

Segal, J. (2011). Melejitkan Kepekaan Emosional: Cara Baru-Praktis untuk Mendayagunakan Potensi Insting dan Kekuatan Emosi Anda. Bandung: Penerbit Kaifa.

Rivai, V. (2009). Kepemimpinan dan Perilaku Organisasi, Cetakan ke-7. Jakarta, PT. Raja Grafindo Persada.

Rivai, V., \& Murni, S. (2009). Education Management; Analisis Teori dan Praktik. Jakarta: Rajawali Pers.

Barnawi \& M. Arifin. 2012 Manajemen Sarana dan Prasarana sekolah. Jogyakarta: $\operatorname{Ar}-\operatorname{Ruzz}$

Hawari, D. (2016). Manajemen Stres Cemas dan Depresi. Jakarta: Fakultas Kedokteran Universitas Indonesia. 
Mangkunegara. (2010). Manajemen Sumber Daya Manusia. Perusahaan. Bandung: PT Remaja Rosdakarya.

Robbins, S. P., \& Judge, T. A. (2012). Organizational Behavior (15th Edition). USA: Prentice Hall.

Luthans, K. W., Luthans, B. C., \& Palmer, N. F. (2016). A positive approach to management education: The relationship between academic PsyCap and student engagement. Journal of Management Development, 35(9), 10981118. https://doi.org/10.1108/JMD-06-2015-0091

Effendi, A. (2015). Revolusi kecerdasan abad 21. Bandung: Alfabeta.

Edison, E., dkk. (2016). Manajemen Sumber Daya Manusia. Alfabeta. Bandung.

Putra, Z. H., \& Sucitra, W. (2015). Hubungan intelegensi dengan hasil belajar matematika siswa kelas V SD Negeri 68 Pekanbaru. Jurnal Pendidikan Matematika UIN Antasari, 2(2), 1-18. https://doi.org/10.18592/jpm.v2i2.1171

Wijayanti, O., \& Rukiyati, R. (2021). Multiple Intelligences in Learning Musical Dramas for Prospective Primary School Teachers. Journal of Teaching and Learning in Elementary Education, 4(1), 95-109. 